\title{
Kistik Ekinokokoz'un serolojik tanısında indirekt hemaglütinasyon, İndirekt Floresan Antikor ve Enzim İmmuno Assay testlerinin etkinliğinin değerlendirilmesi
}

\author{
The evaluation of effectiveness of Indirect Hemagglutination, \\ Indirect Fluorescent Antibody test and enzyme immunoassay \\ in serological diagnosis of cystic Echinococcosis
}

\author{
Sadık Akgün, ${ }^{1}$ Hakan Sezgin Sayiner, ${ }^{2}$ Tekin Kaslıgil $^{3}$ \\ 'Department of Medical Microbiology, Adıyaman University Faculty of Medicine, Adıyaman, Turkey \\ 2Department of Infectious Diseases and Clinical Microbiology, Adıyaman University Faculty of Medicine, Adıyaman, Turkey \\ ${ }^{3}$ Department of Medical Microbiology, Gaziantep University Faculty of Medicine, Gaziantep, Turkey
}

\begin{abstract}
Özet
Amaç: Kistik Ekinokokoz, Echinococcus granulosus'un metasestod formunun sebep olduğu bir helminto-zoonozdur. Kistik ekinokokoz'da klinik özelliklere dayanarak tanı koymak zordur. Bu nedenle spesifik antikorların tanımlanmasına yönelik serolojik yöntemler yaygın olarak kullanılmaktadır. Testlerin duyarlılığı ve özgüllüğü kullanılan yönteme göre değişmektedir. Bu çalışma serumda İndirekt Hemaglütinasyon (IHA), İndirekt Floresan Antikor (IFA) ve Enzim İmmuno Assay (ELISA) yöntemlerinin etkinliğini belirlemek amacı ile yapıldı.

Gereç ve Yöntem: Çalışmamızda Merkez Laboratuvarı'na kist hidatik ön tanısı almış 163 hastanın, serum örneğinde E. granulosus'a karşı oluşan lgG tipi antikorlarının varlığı İndirekt Hemaglütinasyon (IHA), İndirekt Floresan Antikor (IFA) ve Enzim İmmuno Assay (ELI$\mathrm{SA}$ ) testleri ile değerlendirildi. Test sonuçlarının değerlendirlmesinde Western-Blot yöntemi altın standart olarak kullanıldı.

Bulgular: Toplam 163 hastanın serum örneğinde IHA, IFA ve ELISA testleri lgG antikoru sırası ile 83 (\%51), 85 (\%53) ve 70 (\%42.95)'inde pozitifti. Western blot doğrulama testine göre IHA testlerinin duyarlılık ve özgüllük oranları sırası ile; testinin duyarlılığı \%88.76, özgüllüğü \%94.59, IFA testinin duyarlılığı \%89.89, özgüllüğü \%93.24, ELISA testinin duyarlılığı \%78.65, özgüllüğü \%100 olarak saptandı.

Sonuç: Her üç yöntemle elde edilen test sonuçları birbiri ile karşılaştırıldığında istatistiksel olarak anlamlı fark saptanmadı. Bu nedenle IHA yönteminin serumda KE tanısında kullanılabilecek pratik ve ucuz bir yöntem olduğu kanısında varıldı.
\end{abstract}

Anahtar Sözcükler: ELISA; IHA; IFA; kistik Ekinokokoz; Western Blot.

\begin{abstract}
Introduction: The aim of this study was to evaluate serologically type Ig $G$ antibodies against E. granulosus, in 163 patients who referred with the suspicion of Cystic Echinococcosis from various clinics to Laboratory between 2007 and 2008, using Indirect Hemagglutination (IHA) test, by an Indirect Fluorescence antibody (IFA) test, and by an Enzyme-Linked Immunosorbent Assay (ELISA) and to evaluate this antibodies using by Western blot.

Methods: Type Ig G antibodies against E. granulosus in serum samples of patients were investigated by a commercial indirect hemagglutination (IHA) test, by an indirect fluorescence antibody (IFA) test, and by an enzyme-linked immunosorbent assay (ELISA). Results were comfirmed by Western blot method.

Results: Out of 163 patients, 83 (51\%) were positive with IHA, 85 (53\%) were positive with IFA, and 70 (43\%) were positive with ELISA. According to Western blot test, sensitivity and specifity of IHA test were $88.76 \%$ and $94.59 \%$, respectively, for IFA sensitivity was $89.89 \%$ and specificity was $93.24 \%$, and for ELISA sensitivity was $78.65 \%$ and specificity was 100\%

Discussion and Conclusion: As result, IFA and IHA methods were found equally sensitive and specific in the serological diagnosis of cystic hydatidosis, but ELISA method was found more spesific (100\%) when compared to these two methods.

Keywords: ELISA; IHA; IFA; cystic Echinococcosis; Western Blot.
\end{abstract}


$\mathrm{K}$ ist hidatik, özellikle tarım ve hayvancılığın yaygın olduğu ülkelerde sık görülen, çoğunlukla köpek dışkısı ile insana bulaşan bir sestod'un neden olduğu zoonotik bir enfeksiyondur. ${ }^{[1]}$ Son konak tarafından dış ortama atılan parazit yumurtalarının koyun, keçi, sığır ve insan tarafından sindirim veya solunum yolu ile alınmasıyla enfeksiyon oluşabilmektedir. ${ }^{[1-3]}$

Kist hidatik tanısında çeşitli serolojik yöntemlerden yararlanılmıştır. İlk kez 1957'de indirekt hemaglutinasyon (IHA) Garabedian ve ark. ${ }^{[4]}$ tarafından uygulanılmış, kolay uygulanırlığı ve güvenirliliği yönünden tanıda yardımcı bir test olduğu belirtilmiştir. Daha sonra birçok araştırıcı bu testi kullanmış, \%52-93 arasında değişen duyarlılığın kistin yerleşimi ve konağın biyolojik aktivitesi ile ilgili olduğu bildirilmiştir. Bazı araştırıcılar ise enfeksiyonun patojenitesi ile testin duyarlılığının uyumlu olduğunu belirtmişlerdir. Diğer bir yöntem olan indirekt floresan antikor testi (IFA), etkensel tanısı zor olan parazit hastalıklarının teşhisine büyük katkı sağlayan serolojik tanı yöntemlerinden biri olarak kabul edilmektedir. Uygulanışı kolay olduğu, kısa zamanda sonuç alındığı, sonuçları çok duyarlı ve spesifik bulunduğundan dolayı kist hidatik tanısında da tercih edilen bir testtir. ${ }^{[5]} \mathrm{KE}$ tanısında enzyme linked immunosorbent assay (ELISA) ya da enzyme immun assay (EIA) yöntemleri de kullanılmakta olup duyarlılığının yüksek olduğu fakat cysticercosis ile çapraz reaksiyon verdiği bildirilmektedir. ${ }^{[6]}$

Tanının doğrulanması amacıyla Western blot (WB) yönteminden yararlanılmaktadır. WB, hastalıkların prognozunu anlamada diğer serolojik testlerin pek çoğuna göre daha faydalı veriler sunmaktadır. ${ }^{[7,8]}$

Bu çalışmada, kist hidatik ön tanılı serumlarda IHA, IFA ve ELISA yöntemleri ile antikor varlığı araştırılmış ve WB ile bu yöntemlerin birbirine karşı üstünlüğü değerlendirilmiştir. Ayrıca WB ile saptanan antikorların öncelikle hangi antijenlere karşı geliştiği araştırılmış ve bunun kistin yerleşimi ve hastanın kliniği ile ilişkisi değerlendirilmiştir.

\section{Gereç ve Yöntem}

Merkez Laboratuvarı Mikrobiyoloji Bölümü'ne 20.05.2007-
20.05.2008 tarihleri arasında kist hidatik ön tanısı ile gönderilen 163 hastaya ait kan örnekleri serumu ayrıştırılarak toplandı ve kullanılıncaya kadar $-80^{\circ} \mathrm{C}$ 'de saklandı. Hastaların 102'si kadın, 61'i erkek olup yaş ortalaması 39 (1-84) olarak hesaplandı. Hastaların epidemiyolojik özellik gösteren verileri (sosyoekonomik durumları) ve hastalık ile ilgili diğer laboratuar bilgileri, radyolojik bilgiler ve varsa cerrahi bilgileri eşzamanlı olarak hastane arşivinden ve ilgili bölümlerden temin edildi. Çalışmaya alınan hasta serumları rutin istemlerden elde edildiğinden hasta onamı gerekmemektedir.

Kontrol grubu olarak herhangi bir hastalığı olmadığı bilinen kan donörlerinden 4'ü kadın, 26'sı erkek olup yaş ortalaması 28 (17-49) olan toplam 30 kişinin kanları alınıp serumları ayrılarak çalışılıncaya kadar -80 derecede saklandı.

Çalışmaya alınan hastaların serumları ayrıştırıldıktan sonra sırası ile İndirekt Hemaglütinasyon (Fumouze Diagnostics, Paris, Fransa), İndirekt Floresan Antikor (EUROIMMUN Medizinische Labordiagnostika AG, Luebeck, Almanya) ve Enzim İmmuno Assay (EUROIMMUN Medizinische Labordiagnostika AG, Luebeck ,Almanya) ticari kitleri ile üretici firmaların önerileri doğrultusunda yöntemler çalışılarak E. granulosus'a karşı oluşan IgG tipi antikorlar arandı. Elde edilen pozitif sonuçlar, Western blot testi ile üretici firmanın (Anti-Echinococcus granulosus-WB IgG, EUROIMMUN Medizinische Labordiagnostika AG, Luebeck, Almanya) çalışma prosedürü ve önerileri doğrultusunda çalışıldı.

\section{İstatistiksel Analiz}

İstatistiksel analizler bağımsız grup oranlarının karşılaştırılması yapılarak ki-kare $\left(x^{2}\right)$ (chi-square) yöntemleri ve pozitif prediktif ve negatif prediktif değer hesaplanmaları uygulanarak yapıldı.

\section{Bulgular}

Çalışmamızda, IHA testi pozitifliği ile yaş ve cinsiyet grupları irdelendiğinde; $\leq 16$ yaş grubunda 21 hastanın 9'u (\%42.9), Tablo 1. Yaş ve cinsiyetin IHA pozitifliğine göre dağılımı

\begin{tabular}{|c|c|c|c|c|}
\hline \multirow[t]{2}{*}{ Hasta grubu } & \multirow{2}{*}{$\frac{\text { IHA pozitif }}{n(\%)}$} & \multirow{2}{*}{$\frac{\text { IHA negatif }}{n(\%)}$} & \multirow[t]{2}{*}{ Toplam olgu } & \multirow[t]{2}{*}{$\%$} \\
\hline & & & & \\
\hline \multicolumn{5}{|l|}{ Yaş } \\
\hline$\leq 16$ & 9 (42.9) & $12(57.1)$ & 21 & 12.9 \\
\hline $16-45$ & $40(54.8)$ & $33(45.2)$ & 73 & 44.8 \\
\hline$\geq 45$ & $34(49.3)$ & $35(50.7)$ & 69 & 42.3 \\
\hline \multicolumn{5}{|l|}{ Cinsiyet } \\
\hline Kadın & $57(55.9)$ & 45 (43.6) & 102 & \\
\hline Erkek & $26(44.1)$ & 35 (56.4) & 61 & \\
\hline Toplam & 83 & 80 & 163 & \\
\hline
\end{tabular}

IHA: Indirekt hemaglutinasyon 
16-45 arasında 73 hastanın 40'ı (\%54.8), $\geq 45$ yaş grubundaki 69 hastanın 34'ü (\%49.3) seropozitif tesbit edildiğinden yaşla $(p=0.588)$, benzer şekilde, toplam 61 erkek hastanın 26'sı (\%44.1) ve 102 kadın hastanın 57'sinde (\%55.9) seropozitiflik bulunduğundan, cinsiyetle seropozitiflik arasında bir ilişki bulunamadı ( $p=0.101$ ) (Tablo 1).

Çalışmaya alınan 163 hastanın 70'inde (\%43) çeşitli patolojiler mevcuttu. Bunlardan 14'ü hepatobilier [Safra taşı (5), kronik kolesistit (3) ve karaciğer absesi (4), karaciğer adeno CA (1) ve hemanjiyom (1)], 8'i kardiovasküler [hipertansiyon (4), koroner arter hastalığı (2), venöz yetmezlik (2)], 19'u genito-üriner [over kisti (5), vezikoüreteral reflü (2), böbrek/üreter taşı (2), böbrek yetmezliği (3), böbrek kisti (3), varikosel ve inguinal herni (2), memede nodül (1), servikal intraepitelyal neoplazi (2)], 6'sı endokrin [Diabetes Mellitus (4), kronik pankreatit (1), tiroid nodülü (1)], 4'ü pulmoner [KOAH (2), Larinks kanseri (1), akciğerde yabancı cisim (1)], 7'si gastrointestinal patolojiler [peptik ulcus (5), intestinal obstriksiyon (1), omentum tm. (1)], 7'si hematolojik [kanama diyatezi (1), dalak kisti (2) lenfoma (3), Hemofagositik sendrom (1)], 5 hastada iskelet sistemi patolojileri [disk hernisi (3), vertebra'da Schmorll nodülü (1), osteosarkom (1)] vardı. Bu 70 olgunun 46'sında seroloji negatifti. Serolojisi pozitif olan olguların çoğunda genitoüriner (\%27) ve hepatobiliyer (\%20) sisteme ait patolojiler mevcuttu.

Çalışılan 163 olgunun 100'ünde radyolojik olarak kist oluşumu saptanmış olup, olguların \%70'inde karaciğer, \%25'inde akciğer, \%5'inde ise diğer organ tutulumu görülmekteydi. Olguların çoğunluğu tek kist şeklinde olup genellikle karaciğerin sağ lobunu tutmaktaydı.

Çalışmaya alınan 163 hastanın 80'inde IHA ile negatif (1/80) ve altındaki serum dilüsyonu), 83 hastada ise (1/160 dilüsyon ve üzeri) pozitiflik saptandı. Kontrol grubunda (kan donörleri) 2 olguda pozitiflik görüldü.

IFA ile çalışmada 163 hastanın 78'i negatif, 85'i pozitif saptandı.

Tablo 2. IHA, IFA ve ELISA sonuçlarına göre dağılım

\begin{tabular}{|c|c|c|}
\hline \multirow[t]{2}{*}{ Test sonucu } & \multirow{2}{*}{$\frac{\text { Olgu sayısı }}{n(\%)}$} & \multirow{2}{*}{$\frac{\text { Kontrol (kandonörleri) }}{\text { n (\%) }}$} \\
\hline & & \\
\hline \multicolumn{3}{|c|}{ İndirekt Hemaglütinasyon } \\
\hline Pozitif & $83(50.92)$ & $2(6.67)$ \\
\hline Negatif & $80(49.08)$ & $28(93.3)$ \\
\hline Toplam & $163(100)$ & $30(100)$ \\
\hline \multicolumn{3}{|c|}{ İndirekt floresan antikor } \\
\hline Pozitif & $85(52.15)$ & $-(-)$ \\
\hline Negatif & $78(47.85)$ & $30(100)$ \\
\hline Toplam & $163(100)$ & $-(100)$ \\
\hline \multicolumn{3}{|c|}{ Enzim İmmuno Assay } \\
\hline Pozitif & $70(42.9)$ & $-(-)$ \\
\hline Negatif & $93(57.1)$ & $30(100)$ \\
\hline Toplam & $163(100)$ & $30(100)$ \\
\hline
\end{tabular}

Tablo 3. Western blot sonucuna göre diğer testlerin dağlımı

\begin{tabular}{|c|c|c|c|c|}
\hline \multirow[t]{2}{*}{ Testin adı } & \multicolumn{2}{|c|}{ Western Blot } & \multirow[t]{2}{*}{ Toplam } & \multirow[t]{2}{*}{$\%$} \\
\hline & Pozitif & Negatif & & \\
\hline \multicolumn{5}{|c|}{ İndirekt Hemaglütinasyon } \\
\hline Pozitif & 79 & 4 & 83 & 50.92 \\
\hline Negatif & 10 & 70 & 80 & 49.08 \\
\hline \multicolumn{5}{|c|}{ İndirekt floresan antikor } \\
\hline Pozitif & 80 & 5 & 85 & 52.15 \\
\hline Negatif & 9 & 69 & 78 & 47.85 \\
\hline \multicolumn{5}{|c|}{ Enzim Immuno Assay } \\
\hline Pozitif & 70 & 0 & 70 & 42.94 \\
\hline Negatif & 19 & 74 & 93 & 57.06 \\
\hline
\end{tabular}


Tablo 4. Western blot ile Indirekt Hemaglütinasyon, İndirekt floresan antikor ve Enzim İmmuno Assay yöntemlerinin karşılaştırılması

\begin{tabular}{lccc}
\hline & \multicolumn{2}{c}{ Western Blot } & Toplam \\
\cline { 2 - 3 } & Pozitif & Negatif & \\
\hline İndirekt Hemaglütinasyon & & & 83 \\
$\quad$ Pozitif & 79 & 4 & 80 \\
Negatif & 10 & 70 & 163 \\
Toplam & 89 & 74 & 85 \\
İndirekt floresan antikor & & & 78 \\
Pozitif & 80 & 5 & 163 \\
Negatif & 9 & 69 & 70 \\
Toplam & 89 & 74 & 93 \\
Enzim İmmuno Assay & & & 163 \\
Pozitif & 70 & 0 & 74 \\
$\quad$ Negatif & 19 & 74 & \\
Toplam & 89 & 74 & \\
\hline
\end{tabular}

Pozitiflik üretici firmanın önerileri doğrultusunda 1 pozitif, 2 pozitif, 3 pozitif ve 4 pozitif şeklinde değerlendirildi. Kontrol grubunda ise IFA ile pozitiflik saptanmadı.

ELISA ile çalışmada ise 93 hasta negatif, 70 hasta pozitif saptandı. Kontrol grubunda IHA ile 1/160 pozitif bulunan bir olgu ELISA ile de sınır değerde (cut off sınırında) bulundu ve tekrarlanan testlerinde negatif olarak değerlendirildi. Yine kontrol grubunda ELISA ile şüpheli sınırda bir olgu tekrarında negatif bulundu (Tablo 2).

Tüm olgularda doğrulama amacıyla WB uygulandı. IHA, IFA ve ELISA test sonuçlarına göre (her üç yöntemle) negatif değerlendirilen 69 hastanın tümü WB ile negatif değerlendirildi. Bu olgularda herhangi bir antijen bandı görülmedi.

Çalışılan 163 serum örneğinin 94'ünde (\%58) üç yöntemden en az biriyle pozitiflik saptandı. IHA, IFA ve ELISA yöntemlerinden en az biriyle pozitif olarak değerlendirilen 94 hasta serumu ve 2 şüpheli kontrol serumu WB ile araştırıldı. Olguların 66'sı (\%40.49) p7 bandının varlığı nedeniyle pozitif, 23'ü p7 kDa bandı olmayıp, p16/18 ve p24/26 kDa bantların varlığı nedeniyle şüpheli/sınırda ve $5^{\prime} i$ de sadece p39 bandının varlığı nedeniyle negatif olarak değerlendirildi. Geriye kalan 69 örnekte WB'de, herhangi bir antijen bandı görülmeyip negatif bulundu.

IHA pozitif olup, IFA ve ELISA ile negatif saptanan 1 kontrol serumu WB yöntemiyle de negatif saptandı. ELISA ile şüpheli (cut off sınırında) değerlendirilen 1 kontrol serumu diğer yöntemlerle negatif saptandı. IHA ile pozitif saptanan 83 olgunun $79^{\prime} \mathrm{u}$, IFA ile pozitif saptanan 85 olgunun 80'i ve ELISA ile pozitif saptanan olguların tümü WB yöntemiyle pozitif değerlendirilmiştir (Tablo 3).

WB yöntemini, diğer testlerle karşılaştırdığımızda; IHA için duyarlılık \%88.76, özgüllük \%94.59, güvenilirlik $\% 91.41$, pozitif prediktiflik değeri \%95.18, negatif prediktiflik değeri \%87.5 olarak bulundu. WB ile IHA arasındaki anlamlı farklılık saptan- mıştır ( $x^{2}=112.34$ ve $\left.p=0.00\right)$. IFA için duyarlılık \%89.89, özgüllük \%93.24, güvenilirlik: \%91.41, pozitif ve negative prediktiflik değerleri sırasıyla \%94.12, \%88.46 bulundu. WB ile IFA arasında anlamlı farklılık saptanmıştır $\left(x^{2}=111.9\right.$ ve $\left.p=0.00\right)$. ELISA için duyarlılık \%78.65, özgüllük \%100, güvenilirlik $\% 88.34$, pozitif ve negative prediktiflik değerleri sırasıyla \%100, \%79.57 bulundu. WB ile ELISA arasında anlamlı farklılık saptanmıştır $\left(x^{2}=102.01\right.$ ve $\left.p=0.00\right)$ (Tablo 4$)$.

\section{Tartışma}

Kist hidatik hastalığında tanı koydurucu spesifik klinik bulguların olmaması, hastalığın tanısında klinik bulgulardan çok laboratuvar bulgularından yararlanılmasına neden olmuştur. Ancak Kullanılan immunolojik tanı yöntemlerinin özgüllük ve duyarlılıklarının farklı olması ve bazı testlerin \%100 güvenilir sonuç verememesi, duyarlılık ve özgüllüğü daha yüksek olan immunolojik tanı yöntemlerinin geliştirilmesini gerektirmiştir. ${ }^{[9]}$ Çalışmamızda test edilen 163 olgunun 102'si (\%62.58) kadın, 61'i (\%37.42) erkek olup yaş aralığı 1-84, ortalama yaş ise 39 bulundu. Indirekt hemaglütinasyon (IHA) test sonucuna göre pozitif bulunan 83 olgunun 26'sı (\%31.33) erkek, 57'si (\%68.67) de kadındı. Yapılan birçok seroprevalans çalışmasında poziflik oranının kadınlarda anlamlı olarak yüksek olduğu belirtilmektedir. ${ }^{[10-12]}$

Karaman ve ark.nın ${ }^{[1]}$ Kars yöresinde IHA ve IFA yöntemleriyle yaptıkları çalışmada pozitifliğin yaş ve cinsiyet ile ilişkisi açısından anlamlı farklılık saptanamamıştır. Yılmaz ve ark.nın, ${ }^{[13]}$ yaş ve cinsiyet ile $\mathrm{KE}$ arasındaki ilişkiyi araştıran çalışmasında, 303 kadın hastanın 78'inde (\%25.7), 255 erkek hastanın 65'inde (\%25.5); 8-15 yaş grubu 48 cocuk hastanın 16'sında (\%33.3), 15 yaş uzerindeki 510 erişkin hastanın 127'sinde (\%24.9) seropozitiflik saptandığı, yapılan istatistik karşılaştırmada KE'e rastlama sıklığı ile yaş ve cinsiyet arasında anlamlı bir ilişkinin bulunmadığı saptanmıştır ( $p>0.05$ ). Yine, Kılıç ve ark.nın $\left.{ }^{[14]}\right] H A$ ve 
ELISA yöntemleriyle yapmış olduğu çalışmada ve Park ve ark. nın ${ }^{[15]}$ ELISA yöntemiyle yapmış olduğu çalışmada bulgularımız ile uyumlu olarak pozitifliğin cinsiyet ve yaşla ilişkisi olmadığı belirtilmiştir. Ancak Beyhan ve ark.nın ${ }^{[16]}$ yapmış olduğu çalışmada cinsiyete göre sonuçlar incelendiğinde erkeklerin \%13'ünün (153/1177), kadınların ise \%16,4'ünün (286/1744) seropozitif olduğu görülmüştür. Yapılan istatistik karşılaştırmada antikor pozitifliği ile cinsiyet arasındaki farkın anlamlı olduğu bulunmuştur ( $\mathrm{p}=0.013$ ).

Bizim çalışmamızdaki 163 olgunun 102'si (\%62.58) kadın, 61'i (\%37.42) erkek olup yaş aralığı 1-84, ortalama yaş ise 39 bulundu. 16 ve altı yaş grubunda 21 hastanın 9'u (\%42.9), 1645 yaş arası gruptaki 73 hastanın 40'ı (\%54.8), 45 ve üzeri yaş grubundaki 69 hastanın 34'ü (\%49.3) seropozitif olarak tesbit edildiğinden yaşla seropozitiflik arasında bir ilişki bulunamadı $(p=0.588)$. IHA test sonucuna göre pozitif bulunan 83 olgunun 26'sı (\%31.33) erkek, 57'si (\%68.67) de kadındı. Bununla birlikte kadınlardaki pozitiflik oranı (\%55.9) ile erkeklerdeki pozitiflik oranı (\%42.6) istatistiki olarak değerlendirildiğinde anlamlı bir farklılık görülmedi ( $p>0.05$ ).

Diğer çalışmalarda da KE olgularında kistlerin yıllar içerisinde geliştiği ve semptomların geç ortaya çıkması nedeniyle tanının geç konulması sonucu orta ve ileri yaşlarda hastalığa daha sık rastlandığı bildirilmektedir. ${ }^{[11,12,14,17,18]}$ Çalışmamızda IHA ile pozitif saptanan 83 olgunun 9'u (\%10.8) 16 yaşın altında, 39'u (\%46.9) $16-45$ yaş arasında ve 35 'i (\%42) de 45 yaşından büyüktü.

Taş Cengiz ve ark.nın, ${ }^{[6]}$ 2005-2013 tarihleri arasında KE şuphesi ile başvuran toplam 2642 hastaya ait (1214'u erkek, 1428'i kadın; 506'sı 0-13, 2136'sı 14 ve üzeri yaş grubu) kan örneğinin ELISA yöntemi kullanılarak yapılan çalışmasında hastaların 801'i (\%30.3) bu parazitoz yönunden pozitif bulunmuştur. Çalışmada erkeklerin \%31.9'unda, kadınların \%29'unda; 0-13 yaş grubunun \%33.4'ünde, 14 ve uzeri yaş grubunun \%29.6'sında seropozitiflik saptanmıştır. Seropozitif bulunan hastaların opere edilmesi sonucu elde edilen kistlerin unilokuler kist olduğu patolojik olarak teyit edilmiştir. KE sıklığı ile yaş grupları $(Z=1.64 ; p=0.1)$ ve cinsiyetler $(Z=1.61 ; p=0.108)$ arasında istatistiksel olarak anlamlı bir fark belirlenmemiştir. Bizim çalışmamızda, hastaların 70'i (\%42.9) pozitif olarak değerlendirilmiş olup daha yüksek bulunmuştur. Ayrıca, bizim çalışmamızda kistlerin sadece unilokuler olmayıp multilokuler olgular da mevcuttu.

Park ve ark.nın ${ }^{[15]}$ çalışmasında yaşları 15-84 arası değişen KE'lu 66 hasta ile KE'u olmayan 2481 hasta ELISA ile karşılaştırılmış ve duyarlılık \%89.4, özgüllük \%96.4 bulunmuştur. Bizim çalışmamızda ELISA ile duyarlııı \%78.65, özgüllük \%100 olarak yakın değerler elde edilmiştir.

Lopez-Bernus ve ark.nın ${ }^{[19]}$ yaptığı çok merkezli çalışmada, 5510 KE'lu hasta incelenmiş hastaların çoğu (\%88.5) 20 yaş ve üzerindeydi. KE ile birlikte ek hastalıklar araştırıldığında en yaygın kronik hastalığın 1561 (\%28.3) ile kanserler başı çekerken bunu takiben diabetes mellitus 770 (\%14), atrial fibrilasyon ile $562(\% 10.2)$, kalp yetmezliği olanlar 461 (\%8.3), kronik obstruk- tif akciğer hastalığı olan 704 (\%12.8), serebrovasküler hastalıklar 317 (\%5.7) ve kronik böbrek yetmezliği 180 (\%3.3) olarak saptanmıştır. Bizim çalışmamızda ise 163 hastanın 70'inde (\%43) çeşitli patolojiler mevcuttu. Bunlardan 14'ünde hepatobilier, 8'inde kardiovasküler, 19 'unda genito-üriner, 6'sında endokrin, 4'ünde pulmoner, 7'sinde gastrointestinal, 7'sinde hematolojik, $5^{\prime}$ inde iskelet sistemine ait patolojiler vardı. Bu 70 olgunun 46'sında seroloji negatifti. Serolojisi pozitif olan olguların çoğunda genitoüriner (\%27) ve hepatobiliyer (\%20) patolojiler mevcuttu.

Beyhan ve ark.nın ${ }^{[16]}$ yaptığı çalışmada IHA ile 2835 örneğin 431'i (\%15.2), ELISA ile 128 örneğin 11'i (\%8.6) ve WB ile 36 örneğin 4'ü (\%11.1) pozitif tespit edilmiştir. Hem ELISA hem de IHA çalışılan 70 örneğin, 64 (\%91.4) örnek ile uyumlu bulunmuştur. \%7.1 (5 örnek) oranında bir test sınırda iken diğer örnek pozitif/negatif; bir örnekte (\%1.4) ise ELISA ile sonuç negatif ancak IHA ile sonuç pozitif alınmıştır. Örneklerden 58 tanesi WB ile birlikte ELISA/IHA/ELISA+IHA çalışılmış olup \%89.7 (52) oranında uyumlu bulunmuştur. Örneklerden 3'ü' (\%5.2) ile ELISA/IHA sınırda olup WB negatif; ve yine 3 örnekte (\%5.2) ELISA/ IHA pozitif iken WB negatif sonuç vermiştir. Sarı ve ark.nın ${ }^{[20]}$ çalışmasında KE kanıtlanmış olgularda, IHA IFAT ve ELISA yöntemlerinin duyarlılığını sırasıyla $\% 90, \% 82.5$ ve $\% 87.5$ özgüllüğünü ise, \%97.5, \%100 ve \%100 olarak tespit etmişlerdir. Bilge ve ark.nın ${ }^{[2]]}$ çalışmasında IHA testinin özgüllüğünü \%100, duyarlııı̆ını ise \%74.6 olarak saptamışlardır. Akısü ve ark.nın ${ }^{[22]}$ çalışmasında ise IHA testinin duyarlılığı \%96.7 ve özgüllüğü ise \%82.2 olarak bulunmuştur. Çalışmamızda ise Wester blot testini altın standart olarak değerlendirip diğer testlerle karşılaştırdığımızda, IHA testi için duyarlılık \%88.76, özgüllük \%94.59, güvenilirlik \%91.41, pozitif prediktiflik değeri \%95.18, negatif prediktiflik değeri \%87.5 olarak bulundu. IFA testi için duyarlılık \%89.89, özgüllük \%93.24, güvenilirlik: \%91.41, pozitif prediktiflik değeri: \%94.12, negatif prediktiflik değeri: \%88.46 olarak bulundu. ELISA testi için duyarlılık \%78.65, özgüllük \%100, güvenilirlik \%88.34, pozitif prediktiflik değeri \%100, negatif prediktiflik değeri \%79.57 olarak bulundu.

\section{Sonuç}

KE tanısında radyoloji ile seroloji birlikte değerlendirilmelidir. Uygulanan tedavinin takibinde de serolojik test sonuçlarının değerli olması nedeniyle kullanılan bu testlerin duyarlılık ve özgüllüklerinin ve test sonuçlarını etkileyen faktörlerin bilinmesi son derece önemlidir.

Serolojik tanıda kullanılan testlerin duyarlılık ve özgüllüğünün kullanılan yönteme, testte kullanılan antijenin özelliklerine, antijenin kaynağına ve hastanın immun yanıtına göre değişebilmektedir.

Sonuç olarak KE düşünülen hastalarda serolojik testlerin duyarlılık ve özgüllük yönünden biribirine fazla bir üstünlüğü olmadığı, ancak uygulama kolaylığı ve ekonomik oluşu göz önüne alındığında IHA yönteminin KE tanııında kullanılabileceğini düşünmekteyiz. Duyarlıık ve özgüllüğünün yüksek olması 
nedeniyle WB testi, tanı konulamayan olgularda doğrulama amacıyla kullanılabilir. Ayrıca çeşitli antijen bandlarına karşı oluşan antikorların yapısını incelemek amacıyla çeşitli araştırmalarda uygulanabileceğini düşünmekteyiz.

Çıkar çatışması: Bildirilmemiştir.

\section{Kaynaklar}

1. Karaman Ü, Miman Ö, Kara M, Gıcık Y, Aycan ÖM, Atambay M. Kars bölgesinde hidatik kist prevalansı. Turkiye Parazitol Derg 2005;29:238-40.

2. Merdivenci A, Aydınlıkoğlu K. Hidatidoz (hidatik kist hastalığı) İstanbul Üniversitesi Cerrahpaşa Tıp Fakültesi Yayınları 1982:31922.

3. Langer B, Gollinger S. Cystic disease of the liver. In: Surgery of the alimentary tract. Volume III, Edited by Zuidema GD. Philadelphia, W.B. Saunders Co. 1996;531-2.

4. Kuman HA. İndirekt Hemaglütinasyon, Eds; Özcel MA, Altıntaş N. Parazit Hastalıklarında Tanı. Türkiye Parazitoloji Derneği Yayın no 15, İzmir, 1997;193-214.

5. Özcel MA, Üner A, Ertuğ S. Immunofloresans Yöntemi, Eds; Özcel MA, Altıntaş N. Parazit hastalıklarında tanı. Türkiye Parazitoloji Derneği Yayın No 15, İzmir, 1997;215-40.

6. Ak M. Enzyme linked ımmunosorbent assay (ELISA). Eds; Özcel MA, Altıntaş N. Parazit hastalıklarında tanı. Turkiye Parazitol Derg Yayın No:15, İzmir, 1997;241-60.

7. Bulut $H$, Doymaz MZ. Blotlama teknikleri ve mikrobiyolojide kullanımları. Ed: Durmaz R. Uygulamalı moleküler mikrobiyoloji. Malatya, Nobel Tıp Kitapevleri, 2001;123-37.

8. Altıntaş N, Yolasığmaz A. Proteinlerin analizi ve SDS-PAGE, Ed: Özcel MA, Altıntaş N. Parazit hastalıklarında tanı. Turkiye Parazitol Derg Yayın No:15, İzmir, 1997:321-42.

9. Şener S, Yazar S, Şahin I.., Cystıc echınococcosıs'in indirekt fluoresan antikor testi ile tanısında kullanılan antijenlerin tanı değerlerinin araştırılması. Erciyes Üniv. Sağlık Bilim Derg, 2004;13:1-6.

10. Bayram Delibaş S, Özkoç S, Şahin S, Aksoy Ü, Akısü Ç. Dokuz Eylül Üniversitesi Tıp Fakültesi Parazitoloji Anabilim Dalı Seroloji Laboratuvarı'na kistik ekinokokkozis şüphesiyle başvuran hastaların değerlendirilmesi. Turkiye Parazitol Derg, 2006; 30:279-81.

11. Aksoy Ü, İnci A. Kistik ekinokokozisin serolojik tanısında in-house enzim immun yöntemi ve indirekt hemaglütinasyon yönteminin kullanılması. Mikrobiyol Bülteni 2004;38:245-51.
12. Koç NA, Kılıç H, Sözüer E, Taheri JD. Kist hidatik tanılı olgularda indirekt hemaglütinasyon yönteminin önemi ve seropozitiflik oranı. Türk Parazitoloji Dergisi 1996;20:57-60.

13. Yılmaz H, Cengiz ZT, Ciçek M. Unilocular cyst hydatid cases diagnosed between 1998-2005 in the Parasitology Laboratory of Yüzüncü Yıl University Research and Training Hospital. Turkiye Parazitol Derg 2013;37:249-51.

14. Kılıç S, Babür C, Taylan Özkan A. Kist hidatik ön tanılı olgularda indirek hemaglütinasyon ve elısa yöntemleri ile alınan sonuçların karşılaştırılması. Mikrobiyoloji Bülteni, 2007;41:571-7.

15. Park SJ, Han SS, Anvarov K, Khajibaev A, Choi MH, Hong ST. Prevalence of Serum IgG Antibodies to Cystic Echinococcus Antigen among Patients in an Uzbekistan Emergency Hospital. Korean J Parasitol Vol. 53, No. 6: 699-703, December 2015.

16. Beyhan YE, Babür C, Mungan M, Özkan AT. Türkiye Halk Sağlığı Kurumu Ulusal Parazitoloji Referans Laboratuvarı'na 2009-2013 Yılları Arasında Başvuran Kistik Ekinokokkozis Şüpheli Hastaların Değerlendirilmesi Turkiye Parazitol Derg 2015;39:17-21.

17. Karaman Ü, Daldal N, Atambay M, Özlem MA. İnönü Üniversitesi Tıp Fakültesinde 1999-2002 Tarihleri Arasında İncelenen Hidatik Kist Ön Tanılı Olguların Serolojik Sonuçları. İnönü Üniv Tıp Fakültesi Dergisi 2002;233-5.

18. Cengiz ZT, Yılmaz H, Beyhan YE, Kotan MÇ, Cobanoğlu U, Ekici A, et al. Yüzüncü Yıl Üniversitesi Tıp Fakültesi Parazitoloji Laboratuvarına 2005-2013 Yılları Arasında Gönderilen Kan Örneklerinde Kistik Ekinokokkozis Seropozitifliği: Retrospektif Değerlendirme Yüzüncü Yıl Üniversitesi Tıp Fakültesi Parazitoloji.

19. Amparo LB, Moncef BG, Montserrat AS, Adela CP, Virginia VT, Ángela RA, Antonio M, Miguel CS, Javier PL. Surveillance of Human Echinococcosis in Castilla-Leon (Spain) between 2000-2012 PLOS Neglected Tropical Diseases. DOI:10.1371/journal.pntd.0004154 October 20, 2015.

20. Sarı C, Ertuğ S, Karadam SY, Ozgün H, Karaoğlu AO, Ertabaklar H. Kistik ekinokokkozis tanısında ELISA (Enzyme Linked Immunosorbent Assay), İndirekt Hemaglütinasyon Testi (IHA) ve Indirekt Floresan Antikor Testi (IFAT)'nin karşılaştırmalı olarak değerlendirilmesi. Türkiye Parazitol Derg 2009;33:73-6.

21. Bilge UE, Ozdemir M, Baykan M. Kistik ekinokokkozis tanısında ticari İndirekt Floresan Antikor (IFA), İndirekt Hemaglutinasyon (IHA) testleri ve laboratuvarımızda hazırladığımız IFA testinin karşılaştırılması. Türkiye Parazitol Derg 2009;33:195-8.

22. Akisu C, Bayram Delibaş S, Yuncu G, Aksoy U, Ozkoç S, Biçmen C, et al. Evaluation of IHA, ELISA and Western Blot tests in diagnosis of pulmonary cystic hidatidosis. Tuberk Toraks 2005;53:156-60. 